American Journal of Pharmaceutical Education 2019; 83 (7) Article 7465.

\title{
COMMENTARY
}

\section{Service or Disservice? Ensuring Pharmacy Students Provide Authentic Service-Learning}

\author{
Melanie Dicks, PharmD, Trenika Mitchell, PharmD \\ University of Kentucky College of Pharmacy, Lexington, Kentucky \\ Submitted December 18, 2018; accepted May 7, 2019; published September 2019.
}

Service-learning is an academic activity that most US colleges and schools of pharmacy report including in their curriculum. Service-learning can be a valuable form of experiential education that helps to reinforce didactic curricula and develop and refine the soft skills needed for pharmacy practice. However, while providing various forms of service in communities, student pharmacists may not be conducting authentic service-learning. To be considered authentic, service-learning requires the adoption of structured learning outcomes, engaged and prepared students, mutually beneficial experiences for community and students, and completion of student reflection guided with faculty feedback. ${ }^{3-6}$ Considering all of these essential elements, perhaps service-learning is not occurring in communities and pharmacy education today as much as we thought.

Keywords: service-learning, community, experiential education, soft-skills, student reflection

A pharmacy faculty member has just finished precepting her (insert number here) student-led blood pressure screening of the year at a supermarket in an affluent residential neighborhood, and she begins to reflect on the event. Ten students attended and over 40 patients participated. At first glance, she is excited about the number of patients served, but then she begins to view things with a more introspective lens. Three students forgot their stethoscopes and/or blood pressure cuffs. When quizzed, four students could not recall normal versus abnormal blood pressure values as based on current consensus guidelines. All the patients seen for screening had insurance but stopped by the booth because they wanted to provide students a "chance to practice." Most of the patients' blood pressure values were normal, but the students did come to the faculty member with one blood pressure "scare." However, when she spoke to the patient, she learned that he had just smoked a cigarette. He also had not taken his beta-blocker for the past two days and he had come to the supermarket to pick up the refill from the pharmacy.

So, what had really occurred? Yes, the students had served their community, but was it a population that actually needed the service? Had significant learning occurred? What did the students and patients truly gain from the experience? Although this is an exaggerated

Corresponding Author: Melanie Dicks, University of Kentucky College of Pharmacy, 789 S. Limestone St., Lexington, KY 40506. Tel: 859-323-2986. Fax: 859-323-0069. E-mail: melanie.dicks@uky.edu scenario, many preceptors have experienced some level of these concerns, such as unsatisfactory clinical and organizational preparation for a student-led service activity. This can lead to a disservice to both the patients (subpar and lack of targeted care) and students (poor educational and professional experience). Therefore, it is important to understand what authentic service-learning is and how to properly implement it.

The 2001 American Association of Colleges of Pharmacy (AACP) Professional Affairs Committee (PAC) Report makes a clear distinction between community service (volunteerism) and actual service-learning. The report defines service-learning as "a form of experiential education in which students engage in activities that address human and community needs together with structured opportunities intentionally designed to promote student learning and development."1 Service-learning involves "experiences designed to be reciprocal exchanges of knowledge and resources accomplished through service and reflection, and it must be guided by learning outcomes that promote academic and civic engagement as well as focus on holistic learner development and community well-being." " In summary, authentic servicelearning should include: structured experiences tied to predefined learning outcomes; student engagement where each individual is actively involved and adequately prepared; experiences that provide mutual benefit to community (meets population's need) and students (reinforces didactic learning and enhances soft skills); and student self-reflection. ${ }^{3-6}$ 


\section{American Journal of Pharmaceutical Education 2019; 83 (7) Article 7465.}

Although the 2001 PAC Report has described clear, achievable elements of service-learning, a scenario close to that described in the introduction is often what occurs. As a follow-up to the 2001 report, 34 pharmacy schools in the 2013-2014 AACP Academic Leadership Fellows Program were surveyed by the PAC to evaluate the general characteristics of service-learning components found in their programs and if they ultimately met the intent of the 2001 PAC Report and the Accreditation Council for Pharmacy Education (ACPE) Standards. ${ }^{7}$ Schlesselman and colleagues' study concluded that although $100 \%$ of the 34 schools were engaged in community service, each school's method of incorporating the activities into the curriculum and adoption of the service-learning standards set forth in the 2001 report varied. ${ }^{7}$ Specific areas of concern were the inconsistent opportunities offered for student reflection, sparse feedback to students regarding their reflections, and lack of clear learning outcomes. ${ }^{7}$ Based upon these findings, these schools were not engaging in authentic service-learning, which could result in a lack of applied learning for students and optimal service for patients. Due to the difficulty in achieving all of the elements authentic service-learning requires, it is likely that these findings can be expanded to more schools than the 34 mentioned in this study.

Let us return to the scenario. Were the students wrong to conduct the blood pressure screening? No, they were not. What was missing was methodical intention, which ensures that an activity contains all of the elements of authentic service-learning. Both students and faculty members should ensure that future projects impact populations who truly need it, include learning outcomes, and are followed by sincere student reflection and faculty feedback. ${ }^{4,8,9}$

\section{Impacting Populations With Unmet Needs}

Student pharmacists commonly provide care to individuals, especially through student organizational work and efforts. They are highly motivated to share all that they are learning in pharmacy school. However, seldom are students stopping to consider what, if any, needs even exist in a given population. Conducting a thorough needs assessment is imperative to confirm that a given community receives what it actually needs rather than what may be perceived to be needed. Many communities (especially the underserved) are far more appreciative when benefactors ask, research, and determine actual needs before services are provided. Logically, this concept also engenders the most efficient use of time and resources.

Faculty and staff members can serve as great mentors to bridge the gap between student project ideas and actual community needs. ${ }^{8}$ One viable method to propose is to conduct a community needs assessment. A needs assessment is "a systematic set of procedures that are used to determine needs, examine their nature and causes, and set priorities for future action." ${ }^{.10}$ Numerous needs assessment tools exist and can be easily modified to ensure student pharmacists' services directly meet actual needs of the population served. ${ }^{10-13}$

\section{Developing Projects With Learning Outcomes}

While conducting a needs assessment ensures the community benefits from a service project, developing learning outcomes ensures the students benefit as well. Devising predetermined learning outcomes is a critical step in the service project development process. Providing service that is not linked to learning outcomes is merely volunteering. ${ }^{14}$ While volunteering certainly is not a bad thing, it is most ideal for students to serve with purpose and be directed by learning outcomes. ${ }^{14}$ For example, the learning outcome for a service project can be directly related to skills or information acquired in the classroom (eg, properly provide an accurate blood pressure assessment, or educate patients regarding factors that impact blood pressure). The learning outcome can also be one included in the Center for the Advancement of Pharmaceutical Education (CAPE) outcomes for pharmacy education (eg, 3.5 Recognize social determinants of health to diminish disparities and inequities in access to quality care, or 3.6 Effectively communicate verbally and nonverbally when interacting with an individual, group, or organization). ${ }^{15}$

\section{Following Projects With Sincere Student Reflection and Faculty Feedback}

The "gold standard" in the assessment of servicelearning is student reflection. ${ }^{16-20}$ Student reflection is more than a rote writing assignment. Assignments should result in meaningful self-evaluation where minds are intrigued, thoughts are ignited, and hearts are stirred for both the student writing it and the person reading it. A successful reflection is not only on the onus of the student. The assignment should be intentional and well-designed. ${ }^{17}$ Student reflections should indicate an inspection of what was done (service), an evaluation of learning (outcomes), and an examination of self (personal development).

After the student has thoughtfully developed, executed, and evaluated the service project, the final component of true learning and assessment is faculty feedback. Feedback must be timely, frequent, considerate, and constructive. It is not about telling the student what he or she did right or wrong, but instead highlighting what was gained from the experience. Feedback can be written or 


\section{American Journal of Pharmaceutical Education 2019; 83 (7) Article 7465.}

verbal and provided individually or in a group setting. What matters most is that students know their experiences, views, and learning have value. ${ }^{19}$

What can be improved with regards to the scenario provided at the beginning of this article? Conducting a needs assessment guides students to populations who need the service (uninsured, socioeconomically disadvantaged, lack access to healthcare) more than those in the community the students selected. Developing learning outcomes for the event ensures students are prepared and knowledgeable about the health conditions addressed. In the scenario, the preceptor reflected upon the event, but there was no evidence of student reflection. Requiring student reflection coupled with preceptor feedback is essential to the service-learning process and will promote student growth and development.

There are several colleges and schools of pharmacy that have reported positive results concerning authentic service-learning experiences launched in their curricula. The University of North Texas System College of Pharmacy designed an introductory pharmacy practice experience (IPPE) to provide health promotion activities to senior centers. The activities were meticulously planned and, based upon feedback from site directors and program attendees, the services provided were appreciated. Students indicated via survey responses and self-reflection that learning objectives were achieved and they developed an appreciation for public health essential services. Students received additional feedback from the IPPE course director concerning the services they provided. ${ }^{21}$

A two-credit hour elective course entitled, "Learning Through Reflective Service: The Native American Experience," at Creighton University is another example of successfully implemented service-learning. Preparation involved didactic lectures and assigned readings to introduce students to this unique patient population. Creightonand Chinle-based faculty members created learning objectives that specifically met the needs of the students and community. Students were also required to develop personal learning goals. Following course work, there was a week-long immersion experience at an Indian Health Service in Chinle, Arizona, where students worked alongside hospital and clinic pharmacists. For the didactic component of the course, students maintained journals that they shared monthly with instructors and completed daily reflections during their immersion experience. ${ }^{22}$

Finally, at the Massachusetts College of Pharmacy and Health Sciences, School of Pharmacy-Worcester/ Manchester, a required 14-week, one-credit hour course on service-learning was offered to first-year student pharmacists. Based on course service and learning objectives, students provided at least two hours of service per week during the semester at a community site. The course included an additional one-hour didactic session per week that involved periodic pre-class readings and meaningful student discussions. In the latter half of the semester, students gave presentations about their service work and lessons learned. They also journaled weekly based upon designated reflection questions. Example feedback included instructors explaining the connections between their service and pharmaceutical care. To further assess student learning and the service provided, a survey was administered to students and site supervisors. ${ }^{23}$

\section{CONCLUSION}

While these programs provide authentic servicelearning experiences, there is much need for growth in the Academy. Although completing all elements is achievable, it requires collective, intentional effort by both faculty members and students. One of the biggest challenges is the time needed to properly structure learning experiences and ensure that a true service rather than disservice is occurring. It takes time to develop appropriate learning outcomes that are tailored to the purpose of the activity, the needs of the populations served, and the ultimate educational goals for the learner. It takes time to cultivate reciprocal relationships with the community being served. It takes time to develop meaningful reflection assignments. Finally, it takes time to evaluate the service and ensure all outcomes were met both for the student and the community. Although these barriers seem insurmountable, overcoming them is possible. The benefit to the students and the community will be worth the effort.

\section{REFERENCES}

1. Brandt BF. Chair report for the Professional Affairs Committee. Am J Pharm Educ. 2001;65(4;SUPP):19S-25S.

2. University of Kentucky Center for service-learning and civic engagement. Definitions and terminology. http://servelearnconnect.uky.edu/ definitions-and-terminology. Accessed December 17, 2018.

3. Jacoby B. Service-Learning in Higher Education. $1^{\text {st }}$ edition. San Francisco, CA: John Wiley \& Sons, Inc.; 1996. https://www. american.edu/ocl/volunteer/upload/Jacoby-1996.pdf. Accessed December 17, 2018.

4. Jacoby B. Service-Learning Essentials. $1^{\text {st }}$ edition. San Francisco, CA: John Wiley \& Sons, Inc.; 2015. https://books.google.com/books? $\mathrm{hl}=\mathrm{en} \& \mathrm{lr}=\& \mathrm{id}=\mathrm{Q} 0 \mathrm{fxBQAAQBAJ} \& \mathrm{oi}=\mathrm{fnd} \& \mathrm{pg}=\mathrm{PA} 154 \&$

$\mathrm{dq}=$ barbara + jacoby + service + learning $+1996 \&$ ots $=8 \mathrm{TPbW} 7 \mathrm{HhF} \&$ sig $=$ SJ7GHxtOdDp062BIu6E $8 \mathrm{mY7GifI} \# \mathrm{v}=$ onepage $\& \mathrm{q}=$ barbara $\%$ 20jacoby\%20service\%20learning\%201996\&f=false. Accessed December 17, 2018.

5. Howard J. Service-Learning Course Design Workbook. Ann Arbor, MI: OCSL Press; 2001. https://quod.lib.umich.edu/o/ocs1/ 3239521.spec.201. Accessed December 17, 2018. 


\section{American Journal of Pharmaceutical Education 2019; 83 (7) Article 7465.}

6. McCormick K. Service-learning. In E. Anderman \& L. Anderman. Psychology of Classroom Learning: An Encyclopedia. 2008.

Farmington Hills, MI: Thomson Gale.

7. Schlesselman L, Borrego M, Bloom TJ, Mehta B, Drobitch RK, Smith T. An assessment of service-learning in 34 US schools of pharmacy follow up on the 2001 Professional Affairs Committee report. Am J Pharm Educ. 2015;79(8):Article 116.

8. Clayton PH, Bringle RG, Hatcher JA. Research on Service Learning. Volume 2B. Sterling, VA: Stylus Publishing, LLC; 2013. https://www.amazon.com/Research-Service-LearningConceptual-Assessments ebook/dp/B015YFJBOQ/ref=sr_1_1? $\mathrm{s}=$ books \&ie $=\mathrm{UTF} 8 \& \mathrm{qid}=1545090306 \& \mathrm{sr}=1-1 \&$

keywords $=9781579228866$. Accessed December 17, 2018. 9. Felten P, Clayton PH. Service-learning. Evidence Based Teaching. 2011;128:75-84. https://doi.org/10.1002/t1.470. Accessed December 17, 2018.

10. Office of Migrant Education: 2001 New Directors Orientation. https://www2.ed.gov/admins/lead/account/compneedsassessment. pdf. Accessed December 17, 2018.

11. American Academy of Child \& Adolescent Psychiatry. Community needs assessment. https://image.slidesharecdn.com/ communityneedsassessmentform-120302005756-phpapp01/95/ community-needs-assessment-form-1-728.jpg?cb $=1330650390$. Accessed December 17, 2018.

12. Association for Community Health Improvement. 2017. Community health assessment toolkit. www.healthycommunities. org/assesstoolkit. Accessed December 17, 2018.

13. Catholic Health Association of the United States. 2015. Assessing and addressing community health needs. https:// www.chausa.org/communitybenefit/assessing-and-addressingcommunity-health-needs. Accessed December 17, 2018. 14. Furco A. Service-learning: A balanced approach to experiential education. Washington, DC: The corporation for national service; 1996. https://www.shsu.edu/academics/cce/documents/Service_
Learning_Balanced_Approach_To_Experimental_Education.pdf. Accessed December 17, 2018.

15. Medina MS, Plaza CM, Stowe CD, et al. Center for the Advancement of Pharmacy Education 2013 educational outcomes. Am J Pharm Educ. 2013;77(8):Article 162.

16. Astin AW, Vogelgesang LJ, Misa K, et al. Understanding the effects of service-learning: A study of students and faculty. Final report to the Atlantic philanthropies, U.S.A Inc. 2006. https:// www.researchgate.net/publication/266456683_Understanding the_Effects_of_Service-Learning_A_Study_of_Students_and_ Faculty. Accessed December 17, 2018.

17. Ash SL, Clayton PH, Atkinson MP. Integrating reflection and assessment to capture and improve student learning. Michigan Journal of Community Service Learning. 2005;11(2):49-60.

18. Ahmed Z, Hutter L, Plaut J. Reflection in higher education service-learning. Scotts Valley, CA: Learn and serve America's national service-learning clearinghouse. 2005/2008. https:// www.usf.edu/engagement/documents/reflection-in-he-sl-fs-shortsept08.pdf. Accessed December 17, 2018.

19. Eyler J, Giles DE. A practitioner's guide to reflection in servicelearning. Nashville: Vanderbilt University, 1996. https:// leduccenter.files.wordpress.com/2015/02/practitioners-guide-toreflection-in-service-learning.pdf. Accessed December 17, 2018. 20. Moon J. Reflection in Learning and Professional Development. $1^{\text {st }}$ edition. London: Kogan Page Limited, Stylus Publishing, Inc.; 1999. https://www.taylorfrancis.com/books/9781136763649.

Accessed December 17, 2018.

21. Bullock KC. Development, implementation, and evaluation of a service-learning series for pharmacy students using a public health tool. Curr Pharm Teach Learn. 2017; 9(5):828-834.

22. Roche VF, Jones RM, Hinman CE, Seoldo N. A service-learning elective in Native American culture, health and professional practice. Am J Pharm Educ. 2007;71(6):Article 129.

23. Kearney KR. A service-learning course for first-year pharmacy students. Am J Pharm Educ. 2008; 72(4):Article 86. 